\title{
KEANEKARGAMAN SPESIES BURUNG DI KAWASAN HUTAN TAMAN WISATA KARANDANGAN
}

Oleh:

\author{
Apolonius Kartono, Muhamad Soimin, Irna Ningsi Amalia Rachman \\ Program Studi Kehutanan Universitas Pendidikan Mandalika \\ Email: muhammad.soimin01@gmail.com
}

\begin{abstract}
Abstrak
Pulau Lombok merupakan salah satu pulau yang memiliki kenaaekaragaman spesies burung yang tinggi. Salah satu wiayah yang menjadi habitat utamanya dan membutuhkan eksplorasi lebih lanjut terletak di wilayah hutan taman wisata alam Kerandangan. Penelitian eksploratif dilakukan untuk mengobservasi dan mengientifikasi spesies burung yang berada di sekitar hutan taman wisata. Observasi lapangan dilakukan pada bulan Desember 2019 dengan metode transek garis dengan menetapkan 3 transek. Hasil observasi menunjukkan bahwa terdapat 16 spesies burung yaitu: Galus-galus, Hypothymis azuera, Dicaeum manaei, Collocalia linchi, Columba vitiensis, Zoterops chloris, Cinnyris iugualaris, Pitta elegans, Centropus bengalensis, Todiramphus chloris, Philemon buceroides, Alcedo ceorulescens, Artamus leucorynchus, Orthotomus epium, Meaapodius reinwardt dan Ducuela arnea. Spesies yang paling mendominasi adalah Walet Linci (Collocalia linchi) dengan nilai dominansi 0,27 dan dijumpai sepanjang observasi sebanayk 37 ekor. Tingkat keanekaragaman burung berkategori sedang, artinya bahwa keberadaan hutan taman wisata Kerandangan sebagai habitat burung masih dapat dikatakan baik. Hasil penelitian ini hendaknya dapat digunakan sebagai acuan dalam merancang strategi konservasi dengan memperhatikan jenis vegetasi karena berkaitan dengan pakan ketersediaan pakan.
\end{abstract}

Kata kunci: Keanekaragaman, spesies, burung, taman wisata alam Kerandangan

\section{PENDAHULUAN}

Indonesia sebagai negara tropis degan bentang hutan tropis yang sangat luas memiliki keanekaragaman burung yang cukup tinggi. Tingginya keanekaragaman jenis burung di suatu wilayah didukung oleh tingginya keanekaragaman habitat karena habitat bagi satwa liar secara umum berfungsi sebagai tempat untuk mencari makan, minum, istirahat, dan berkembang biak (Alikodra, 2002). Berdasarkan pada fungsi tersebut, maka keanekaragaman jenis burung juga berkaitan erat dengan keanekaragaman tipe habitat serta beragamnya fungsi dari setiap tipe habitat. Kelestarian burung dapat dipertahankan dengan melakukan konservasi jenis yang didahului dengan berbagai studi atau penelitian tentang satwa tersebut, antara lain jenis burung, jumlah individu jenis burung dan penyebaran burung. Burung merupakan suatu obyek konservasi biodiversitas karena manfaat ekologis mauun ekonomis, yaitu sebagai komoditi ekonomi dan untuk menjaga kestabilan ekosistem (Prasetyo, 2002). Atas dasar peran dan manfaat tersebut, maka kehadiran burung dalam suatu ekosistem perlu dipertahankan (Arumasari, 1989). Akan tetapi, akhir-akhir ini keberlangsungan hidup burung semakin lama semakin terdesak yang sebagian besar disebabkan oleh manusia dengan merusak habitatnya, seperti konversi lahan untuk permukiman, peternakan, perkebunan, perindustrian, pertambangan dan lainnya. Kegiatan-kegiatan tersebut membutuhkan lahan yang cukup luas, sehingga habitat burung semakin berkurang dengan bertambahnya kegiatan yang dilakukan oleh manusia untuk memenuhi kebutuhan hidupnya. Perkembangan kota yang semakin luas juga menyebabkan vegetasi habitat burung semakin berkurang sehingga tidak ada tempat bagi burung untuk dapat berkembang biak dengan baik. Kegiatankegiatan tersebut dapat menyebabkan kepunahan yang melampaui tingkat pengembaliannya (Primack et al. 1998).

Menurut data yang di himpun Organisasi Burung Indonesia, jumlah jenis burung di Indonesia bertambah dari awalnya, 1.771 jenis pada 2018 menjadi 1.777 jenis pada awal 2019. Dari seluruh jenis tersebut, 168 jenis burung 
dinyatakan terancam punah dan 30 dari 168 jenis burung dinyatakan berstatus kritis oleh IUCN. Data burung disuatu kawasan juga sangat diperlukan untuk pengelolaan dan perencanaan pembangunan.

Di Pulau Lombok khususnya, terdapat lima lokasi Taman Wisata Alam salah satunya adalah Taman Wisata Alam Kerandangan yang menjadi habitat penting bagi burung. Taman Wisata Alam (TWA) Kerandangan merupakan kawasan hutan lindung Rinjani. Taman Wisata Alam Kerandangan di tetapkan berdasarkan Keputusan Menteri Kehutanan No. 494/Kpts/II/1992 tanggal 1 Juni 1992 dengan luas lebih kurang 320 ha dan terletak di desa Senggigi. Potensi alam yang relatif terjaga, menjadikan hutan taman wisata alam Kerandangan kaya akan keanekaragaman tumbuhan maupun satwa. Menurut Desmawati (2010) burung merupakan plasma nutfah yang memiliki keunikan dan nilai yang tinggi baik nilai ekologi, ilmu pengetahuan, wisata dan budaya. Penelitian tentang burung merupakan hal yang sangat penting karena burung bersifat dinamis dan mampu menjadi indikator perubahan lingkungan yang terjadi pada tempat burung tersebut berada. Hal ini dikarenakan burung merupakan vertebrata yang mudah terlihat secara umum, mudah diidentifikasi, persebaran yang luas, namun dalam pengelolaan dan konservasi cenderung tidak banyak dilakukan di wilayah yang kelimpahan burungnya tinggi termasuk Indonesia. Oleh karena itu, maka penelitian tentang studi keanekaragaman jenis burung di kawasan hutan taman wisata Kerandangan perlu di lakukan sebagai bagian untuk memperbaharui informsi saintifik tentang keberadaan spesies burung tersebut sebagai dasar informasi untuk melakukan manajemen dan konservasi alam, termasuk hutan taman wisata serta biodiversitas burung yang terdapat di dalamnya.

\section{METODOLOGI PENELITIAN}

\section{a. Lokasi dan Waktu Penelitian}

Penelitian dilaksanakan pada bulan Desember tahun 2019 dan berlokasi di kawasan hutan taman wisata alam Kerandangan, Desa Senggigi, Kecamatan Batu Layar, Kabupaten Lombok Barat.

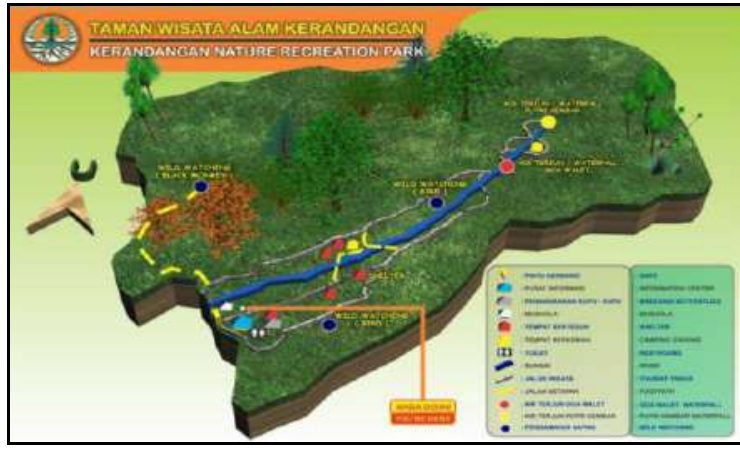

Gambar 1. Peta lokasi penelitian yang terletak di kawasan hutan taman wisata Kerandangan (Sumber: BKSDA Nusa Tenggara Barat 2018).

\section{b. Observasi}

Penelitian ini merupakan penelitian deskriptif eksploratif dengan observasi langsung di lapangan. Teknik pengumpulan data tentang studi keanekaragaman jenis burung di kawasan hutan taman wisata alam Kerandangan dilakukan dengan menggunakan metode transek dikombinasikan dengan metode titik hitung. Pengamatan dilakukan dengan berjalan menelusuri jalur sampai pada titik berikutnya dengan jarak $300 \mathrm{~m}$ antar titik. Selanjutnya, spesies burung yang teramati sepanjang jalur pengamatan dicatat. Pengamatan dilakukan pada waktu pagi hari.

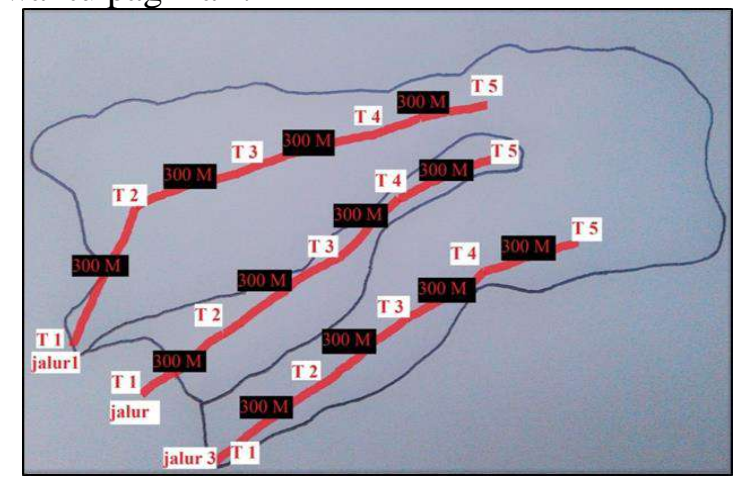

Gambar 2. Desain transek dan titik observsi yang terdiri dari 3 transek dan total 15 titik obsrvasi dengan jarak masing -masing $300 \mathrm{~m}$ antar titik.

\section{c. Analisis Data}

Analisis keanekaragaman komunitas antara lain melalui pendekatan berdasarkan perbandingan indeks keanekaragaman (Odum, 1983), yaitu:

1. Indeks dominansi $(\mathrm{C})$

$$
C=\Sigma\left(\frac{n i}{N}\right)^{2}
$$

Dimana:

$n i=$ Jumlah individu suatu jenis

$\mathrm{N}=$ Jumlah individu seluruh jenis 
2. Indeks Keanekaragaman Jenis (H') Shannon Wiener

$\mathrm{H}^{\prime}=-\Sigma \mathrm{Pi} \ln \mathrm{Pi}$

$P i=\left(\frac{n i}{N}\right)$

Dimana:

$\mathrm{H}^{\prime}=$ Indeks keanekaragaman spesies

$\mathrm{N}=$ jumlah individu seluruh spesies

$n i=$ jumlah indidvidu spesies ke-i ke-i

$\mathrm{Pi}=$ jumlah proporsi kelimpahan satwa spesies

$\ln =$ logaritma natural

Jika satu komunitas hanya memiliki satu spesies maka $\mathrm{H}^{\prime}=0$. Semakin tinggi nilai $\mathrm{H}^{\prime}$ menunjukkan bahwa jumlah spesies makin tinggi serta kelimpahan relatifnya juga semakin tinggi (Odum, 1983). Tingkat keanekaragaman merujuk pada ketentuan ang dikemukakan oleh Krebs (1985) yaitu, apabila H' > 3 indeks keanekaragaman tinggi, apabila $\mathrm{H}^{\prime}=2-3$ indeks keanekaragaman sedang, dan apabila $\mathrm{H}^{\prime}<2$ indeks keanekaragaman rendah.

\section{HASIL DAN PEMBAHASAN}

\section{a. Status Konservasi}

Seluruh spesies burung yang teramati dalam proses observasi di taman wisata Karandangan memiliki status perlindungan, baik itu yang telah ditetapkan oleh IUCN maupun pemerintah melalui Balai Konservasi Sumber Daya Alam (BKSDA).

\section{b. Hasil Observasi}

Berdasarkan hasil observasi lapangan yang dilakukan di hutan taman wisata Kerandangan didapatkan 16 spesies burung, yang terdiri dari Ayam Hutan Merah (Galus galus) 3 ekor, Kehicap Ranting (Hypothymis azuera) 11 ekor, Cabe Lombok (Dicaeum mauaei) 7 ekor, Walet Linci (Collocalia linchi) 37 ekor, Merpati Hutan Metalik (Columba vitiensis) 12 ekor, Kacamata Laut (Zoterops chloris) 6 ekor, Isap Madu Sriganti (Cinnyris iugularis) 9 ekor, Paok Laus (Pitta elegans) 6 ekor, Bubut Alang-alang (Centropus bengalensis) 5 ekor, Cekakak Sungai (Todiramphus chloris) 7 ekor, Cikukua Tanduk atau Koakiau (Philemon buceroides) 6 ekor, Raja Udang Biru (Alcedo ceorulescens) 6 ekor, Kekep Babi (Artamus leucorynchus) 3 ekor, Cinenen Jawa (Orthotomus epium) 10 ekor, Gosong Kaki Merah (Meaapodius reinwardt) 4 ekor, dan Pergam Hijau (Ducula aenea) 3 ekor. Detail jumlah setiap spesies yang ditemukan ditunjukkan pada Gambar 3. Pada diagram batang tersebut terlihat jumlah populasi setiap spesies butung bervariasi. Akan tetapi, spesies burung Walet Linci (Collocalia linchi) mendominasi secara signifikan dengan jumlah mencapai 37 ekor, sementara populasi spesies paling rendah adalah Ayam Hutan Merah (Gallus gallus), Bubut Alang-Alang (Centropus bengalensis), dan Pergam Hijau (Ducula aenea) masing-masing berjumlah 3 ekor.

\begin{tabular}{|c|c|c|c|c|}
\hline Spesies & $\begin{array}{l}\text { Nama } \\
\text { ilmiah }\end{array}$ & Famili & $\begin{array}{l}\text { Jenis } \\
\text { pakan* }\end{array}$ & $\begin{array}{l}\text { Status } \\
\text { konservasi* }\end{array}$ \\
\hline $\begin{array}{l}\text { Ayam } \\
\text { Hutan } \\
\text { Merah }\end{array}$ & Galus galus & Phasianidae & serangga & IUCN \\
\hline $\begin{array}{l}\text { Bubut } \\
\text { Alang- } \\
\text { alang }\end{array}$ & $\begin{array}{l}\text { Centropus } \\
\text { bengalensis }\end{array}$ & Cuculidae & serangga & IUCN \\
\hline $\begin{array}{l}\text { Cabe } \\
\text { Lombok }\end{array}$ & $\begin{array}{l}\text { Dicaeum } \\
\text { mauaei }\end{array}$ & Dicaeidae & buah/biji & IUCN \\
\hline $\begin{array}{l}\text { Cekakak } \\
\text { Sungai }\end{array}$ & $\begin{array}{l}\text { Todiramphus } \\
\text { chloris }\end{array}$ & Alcenidae & ikan & $\begin{array}{lr}\text { IUCN, } & \text { UU } \\
\text { No. } 5 / 1990, \\
\text { PP } & \text { No. } \\
7 / 1999 & \end{array}$ \\
\hline $\begin{array}{l}\text { Cikukua } \\
\text { Tanduk }\end{array}$ & $\begin{array}{l}\text { Philemon } \\
\text { buceroides }\end{array}$ & Meliphagidae & nektar/bunga & $\begin{array}{lr}\text { IUCN, } & \text { UU } \\
\text { No. } 5 / 1990, \\
\text { PP } & \text { No. } \\
7 / 1999 & \\
\end{array}$ \\
\hline $\begin{array}{l}\text { Cinenen } \\
\text { Jawa }\end{array}$ & $\begin{array}{l}\text { Orthotomus } \\
\text { epium }\end{array}$ & Silviidae & serangga & IUCN \\
\hline $\begin{array}{l}\text { Gosong } \\
\text { Kaki } \\
\text { Merah }\end{array}$ & $\begin{array}{l}\text { Meaapodius } \\
\text { reinwardt }\end{array}$ & Megapodiidae & buah/biji & IUCN \\
\hline $\begin{array}{l}\text { Isap } \\
\text { Madu } \\
\text { Sriganti }\end{array}$ & $\begin{array}{l}\text { Cinnyris } \\
\text { iugularis }\end{array}$ & Nectariniidae & nektar/bunga & $\begin{array}{lr}\text { IUCN, } & \text { UU } \\
\text { No. } 5 / 1990, \\
\text { PP } & \text { No. } \\
7 / 1999 & \\
\end{array}$ \\
\hline $\begin{array}{l}\text { Kacamata } \\
\text { Laut }\end{array}$ & $\begin{array}{l}\text { Zoterops } \\
\text { chloris }\end{array}$ & Zosteropidae & serangga & IUCN \\
\hline $\begin{array}{l}\text { Kehicap } \\
\text { Ranting }\end{array}$ & $\begin{array}{l}\text { Hypothymis } \\
\text { azuera }\end{array}$ & Muscicapidae & serangga & IUCN \\
\hline $\begin{array}{l}\text { Kekep } \\
\text { Babi }\end{array}$ & $\begin{array}{l}\text { Artamus } \\
\text { leucorynchus }\end{array}$ & Artamidae & serangga & IUCN \\
\hline $\begin{array}{l}\text { Merpati } \\
\text { Hutan } \\
\text { Metalik } \\
\end{array}$ & $\begin{array}{l}\text { Columba } \\
\text { vitiensis }\end{array}$ & Columbidae & buah/biji & IUCN \\
\hline $\begin{array}{l}\text { Paok } \\
\text { Laus }\end{array}$ & Pitta elegans & Pittidae & serangga & IUCN \\
\hline $\begin{array}{l}\text { Pergam } \\
\text { Hijau }\end{array}$ & $\begin{array}{l}\text { Ducula } \\
\text { aenea }\end{array}$ & Columbidae & buah/biji & IUCN \\
\hline $\begin{array}{l}\text { Raja } \\
\text { Udang } \\
\text { Biru }\end{array}$ & $\begin{array}{l}\text { Alcedo } \\
\text { ceorulescens }\end{array}$ & Alcenidae & ikan & $\begin{array}{lr}\text { IUCN, } & \text { UU } \\
\text { No. } & 5 / 1990, \\
\text { PP } & \text { No. } \\
7 / 1999 & \\
\end{array}$ \\
\hline $\begin{array}{l}\text { Walet } \\
\text { Linci }\end{array}$ & $\begin{array}{l}\text { Collocalia } \\
\text { linchi }\end{array}$ & Apodidae & serangga & IUCN \\
\hline
\end{tabular}

Berdasarkan gambar 4, presentase famili yang paling tinggi yaitu Apopidae. Hal ini juga terkonfirmasi pada gambar 3 karena anggota famili Apopidae yang paling banyak dijumpai di lapangan adalah spesies Walet Linci (Collocalia linchi). 


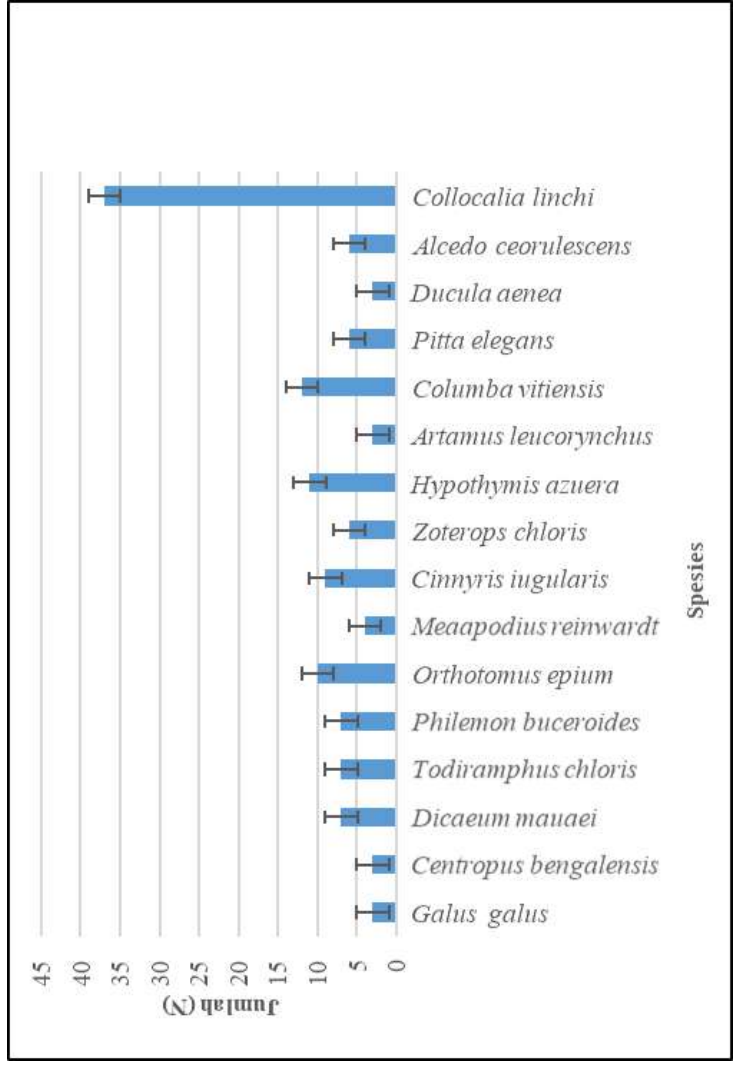

Gambar 3. Diagram batang jumlah spesies burung yang teramati di hutan taman wisata alam Kerandangan.

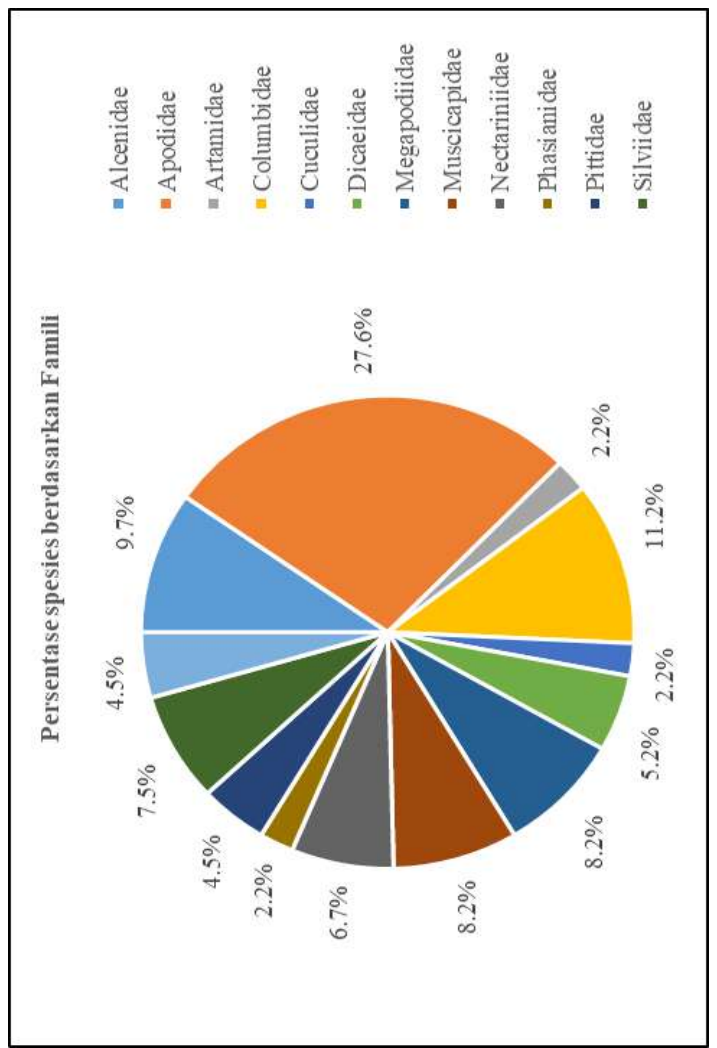

Gambar 4. Diagram lingkaran presentase burung berdasarkan famili. Presentase keteramatan tertinggi termasuk ke dalam famili Apopidae

\section{c. Keanekaragaman Spesies}

Hasil analisis data terhadap dominansi spesies didapatkan bahwa Walet Linci (Collocalia linchi) memiliki nilai dominansi paling tinggi sesuai dengan frekuensi keteramatan sebanyak 37 ekor. Sedangkan nilai dominasi yang paling rendah juga sesuai dengan jumlah kemunculan 3 spesies yang rendah, yaitu Ayam Hutan Merah (Gallus gallus), Bubut Alang-Alang (Centropus bengalensis), dan Pergam Hijau (Ducula aenea) masing-masing dengan nilai dominansi kurang dari 0,050. Frekuensi keteramatan ketiga spesies tersebut juga hanya dijumpai sebanyak 3 ekor. Nilai indeks keanekaragaman Shannon Wiener yaitu $\mathrm{H}^{\prime}=2,47$ berkategori sedang sesuai dengan kategori yang ditetapkan Krebs. Jika suatu komunitas hanya memiliki satu spesies maka $\mathrm{H}^{\prime}$ $=0$. Makin tinggi nilai $\mathrm{H}^{\prime}$ menunjukan jumlah spesies dan kelimpahan relatifnya semakin tinggi (Tjahjono, 1998).

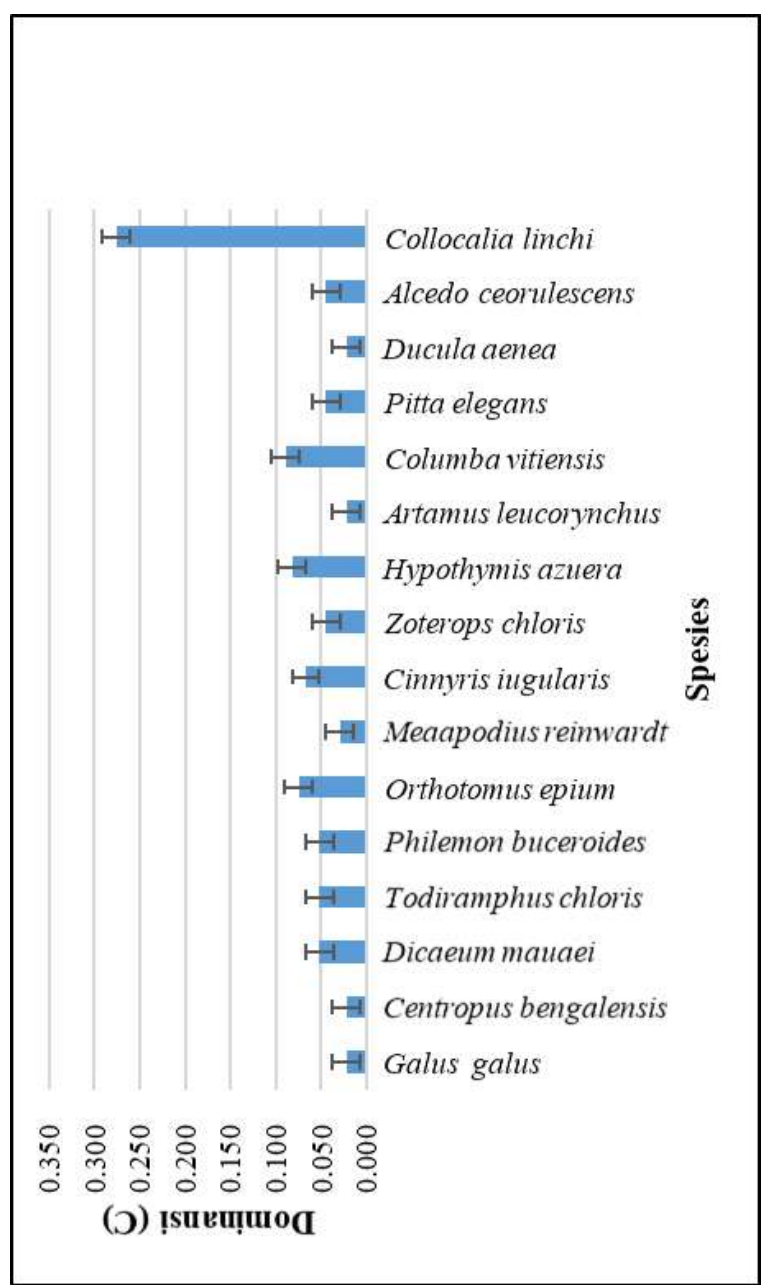

Gambar 5. Diagram batang nilai dominansi (C) setiap spesies. Nilai dominansi menunjukkan variasi, akan tetapi Walet Linci (Collocalia linchi) memiliki nilai dominansi tertinggi. 


\section{d. Implikasi Hasil Observasi Terhadap Upaya Konservasi Burung}

Hasil yang ditunjukkan pada gambar 3, 4, dan 5 kemudian dieksplorasi lebih jauh untuk memberikan rekomendasi lebih lanjut terhadap kebijakan rekomendasi usaha konservasi burung di kawasan taman wisata Kerandangan. Oleh karena itu, spesies burung yang termati didkelompokkan berdasarkan jenis pakannya, yaitu pemakan serangga, pemakan buah dan bijibijian, pengisap madu/nectar pada bunga, dan pemakan ikan dan katak. Berdasarkan hasil analisis, didapatkan masing-masing dengan presentase $59 \%$, 19\%, 12\%, dan $10 \%$ secara berurutan.

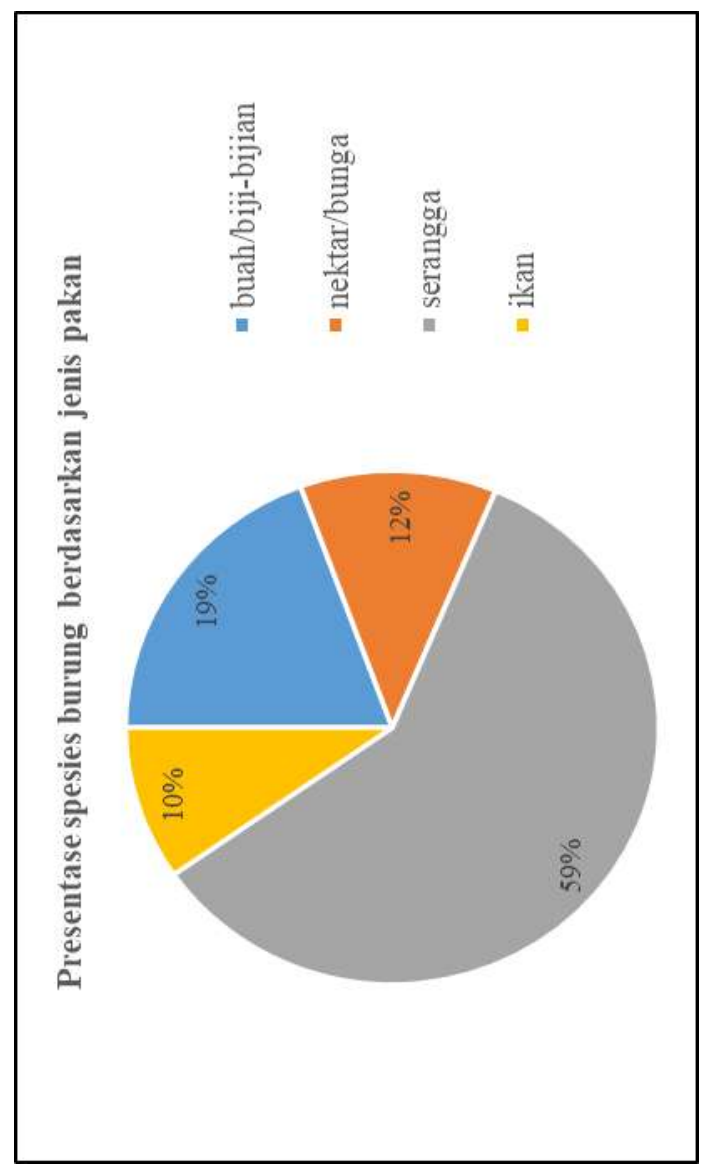

Gambar 6. Diagram lingkaran menunjukkan presentase spesies burung berdasarkan jenis pakan. Jenis burung pemakan serangga memiliki presentase paling tinggi sebesar 59\%, sementara itu burung pemakan ikan memiliki presentase terendah.

Banyaknya jenis burung pemakan serangga diduga berkaitan dengan ketersediaan serangga di lokasi kawasan taman wisata. Saat dilakukan pengamatan hanya sedikit sekali vegetasi yang sedang berbuah, sehingga jenis burung pemakan buah dan biji-bijian hanya ditemukan sebanyak 6 jenis. Oleh karena itu, dapat dikatakan bahwa ketersedian pakan juga berkaitan dengan keteramatan burung. Hutan Kerandangan juga dikategorikan sebagai hutan sekunder yang tidak terlalu lebat. Oleh karena itu, ketersediaan buah/biji untuk burung pemakaan biji tidak terlalu banyak. Sementara itu burung pemakan serangga, selain memanfaatkan kanopi sebagai tempat mencari makan, juga memanfaatkan serangga permukaan tanah sebagai sumber pakan.

Sebagaimana diketahui bahwa hutan taman wisata Kerandangan juga menjadi objek ekowisata pengamatan burung (Birdwatching). Oleh karena itu, pendekatan konservasi untuk menjaga keberlangsungan hidup burung di wilayah tersebut hendaknya memperhatikan keberadaan vegetasi. Hal ini diakibatkan karena keberadaan vegetasi yang cukup memiliki kaitan erat dengan ketersediaan pakan burung (Dewi et al., 2007).

\section{KESIMPULAN}

Berdasarkan uraian di atas diperoleh kesimpulan bahwa terdapajt 16 spesies burung yang berbeda di kawasan hutan taman wisata Kerandangan, yaitu Ayam Hutan Merah (Galus galus), Kehicap Ranting (Hypothymis azuera), Cabe Lombok (Dicaeum mauaei), Walet Linci (Collocalia linchi), Merpati Hutan Metalik (Columba vitiensis), Kacamata Laut (Zoterops chloris), Isap Madu Sriganti (Cinnyris iugularis), Paok Laus (Pitta elegans), Bubut Alang-alang (Centropus bengalensis), Cekakak Sungai (Todiramphus chloris), Cikukua Tanduk/koakiau (Philemon buceroides), Raja Udang Biru (Alcedo ceorulescens), Kekep Babi (Artamus leucorynchus), Cinenen Jawa (Orthotomus epium), Gosong Kaki Merah (Meaapodius reinwardt), dan Pergam Hijau (Ducula aenea). Spesies yang paling mendominasi adalah Walet Linci (Collocalia linchi) dengan nilai dominansi 0,27 dan dijumpai sepanjang observasi sebanayk 37 ekor. Hal ini juga menempatkan family Apopidae dengan presentase tertinggi yaitu $27,6 \%$.

Indeks keanekaragaman Shannon Wiener menunjukkan kategori sedang dengan nilai $\mathrm{H}^{\prime}=$ 2,47 yang artinya bahwa keberadaan hutan taman wisata Kerandangan sebagai habitat burung masih dapat dikatakan baik. Akan tetapi, jika melihat presentase jenis burung berdasarkan pakannya, maka strategi konservasi burung perlu memperhatikan jenis vegetasi yang tumbuh di kawasan taman wisata. Ke depan, jika perlu dilakukan reforestasi, maka jenis vegetasi 
berbunga, berbuah, serta vegetasi yang mengundang keberadaan serangga perlu diperbanyak.

Penelitian rutin juga perlu dilakukan mengingat observasi ini hanya dilakukan secara temporal pada bulan Desember karena kemungkinan beberapa jenis burung ada yang datang dan juga pergi berkaitan dengan musim yang tentunya juga berkaitan erat dengan keberadaan pakan. Penelitian rutin ini juga memungkinkan untuk mengamati jenis burung apa yang ada di kawasan taman wisata Kerandangan pada saat musim penghujan dan juga musim kemarau. Hal ini tentunya akan memberikan dasar informasi yang lebih komprehensif bagi pihak terkait dalam merancang strategi konservasi yang lebih baik.

\section{DAFTAR PUSTAKA}

Alikodra, H. S. 2002. Pengelolaan Satwa Liar.Jilid I. Fakultas IPB. Bogor.

Arumasari. 1989. The Book of Bird Life. Van Nostrand Company Inc. New York.

Balai Konservasi Sumber Daya Alam Nusa Tenggara Barat (BKSDA NTB) 2018.

Desmawati, I. 2010. Studi Distribusi Jenis-Jenis Burung Dilindungi Perundang-undangan.

Dewi, R. S. Yeni M. dan Yanto S. 2007. Keanekaragaman Beberapa Jenis Burung di Beberapa Tipe Taman Nasional Gunung Ciremai. Media Konservasi, 114-118.

Eugene, P. Odum. 1983. Fundamental of Ecology.

Hery Kusumanegara et al. 2018. "Bururngburung Taman Nasional Bali Barat”.

Indrawan, M., Primack, R.B., \& Suptriana, J. (2012). Biologi Konservasi. Jakarta: yaysan pustaka obor indonesia.

Primack, J.B., J. Supriatna, M. Indriawan \& P. Kramadibrata. 1998. Biologi Konservasi Yayasan Obor Indonesia. Jakarta.

Prasetyo, DK. 2002. Studi Habitat Sekitar Sarang Elang Jawa (Spizaetus bartelsi) Di Kawasan Cibolau Taman Nasional GedePangrango Jawa Barat. Jurusan Biologi FMIPA UNDIP. Semarang.

Saleh, Amin. 2018. "Koakiau dan Beberapa Burung Penting di Nusa Tenggara Barat". 